\title{
The Development of Collaborative Learning in The Frame work of Learning Developmnet HE 4.0
}

\author{
B. Tjahjono ${ }^{1}$, R. Susanto ${ }^{2}$, Yulhendri ${ }^{3}$ \\ ${ }^{1}$ Computer Science Faculty, EsaUnggul University, Jakarta, Indonesia \\ ${ }^{2}$ Teacher and Education Science Faculty, EsaUnggul University, Jakarta, Indonesia \\ ${ }^{3}$ Computer Science Faculty, EsaUnggul University, Jakarta, Indonesia
}

Corresponding author:

Email :budi.tjahjono@esaunggul.ac.id

\begin{abstract}
.
This study reports the development of an adaptive collaborative learning framework in the industrial era 4.0. The development of learning models in schools is determined by the ability of teachers in pedagogy and the ability of the technology used. The purpose of this study is to develop a collaborative learning model in terms of student-centered learning in addition to interactive learning that will determine the success of the learning management system. Respondents of this study were 310 primary school teachers in West Jakarta, DKI Jakarta Province. The research methodology used the Structured Equation Model (SEM), Obtained by using the fit model testing $72.01 \%$ and $66.45 \%$ and $r$ square as much as $110.86 \%$ and $94.16 \%$ for the parameters of Collaborative Learning and Learning Management System. This study uses a standard loadings factor of 0.7. The results showed that all loadings factor values for each indicator were $>0.7$. Research findings indicate an influence between interactive learning, collaborative, usercentered learning, and learning management systems.

Keywords: learning, interactive, collaborative, user, centered, management-system
\end{abstract}

\section{INTRODUCTION}

Learning from The industrial revolution era 4.0 has been increasingly wide open and should be separated from a class that only takes place with four walls. This meaning has been very explicit with factual field data which shows that $>55 \%$ of formal organizations experience a digital talent gar. [1] So education should have a link with the development of science and technology that still gives a humanistic touch. The consequence was the need for technological literacy and human literacy in forming Gen_RI 4.0, namely the human cognitive ability to think critically, systemically, laterally and at high levels is formed through an integrated learning process through technological and social literacy. [2] This ability has been needed to be supported through creative and innovative collaborative activities. [3]. For this reason, the challenge of educators in the industrial revolution era4.0 should have digital application competence, supporting students to have the ability to apply technology and strategies to face technological change through innovative ideas and creativity. [4] [5] So education in the era of the industrial revolution demanded stakeholders with a change in management of learning management based on science and technology. The focus of learning was no longer only student centered learning but also how collaborative learning emphasizes the interactive learning process. For this learning conditioning, it requires a learning management system (LMS) which is a trigger for learning that is able to facilitate the critical and creative thinking skills of students [6]

But in reality, in the of the industrial revolution era4.0, the learning development model has not shifted from the decline in school ability which is rooted in the ability of teachers who are still very low both in terms of pedagogical abilities and from content and technology skills (Technological Pedagogical and Content Knowledge / TPACK) as stated in a description of the focus of Sustainable Professional Development (PKB) based on Permenagpan-RB Number 16 of 2009) and Government Regulation (PP) Number 74 of 2008. [7]

For this reason, the downturn has been needed to be answered by utilizing the advancement of Raspberry Pi technology so that it can become access to cheap, easy learning resources with the Learning 
Management System (LMS) and is based on 3 pillars of learning, namely: Student Centered Learning (SCL), Collaborative Learning (CL) and Interactive Learning (IL)This paper presents model development of Student Centered Learning, Interactive Learning (IL), Collaborative Learning and Learning Management System

\section{METHODS}

The method of collecting research data using a survey, is a systematic investigation by collecting information related to an object of study, using a structured questionnaire or list of questions. Data collection used a questionnaire with a Likert scale and interviews with 310 teacher respondents from 16 research school partners in the District Education Office II, West Jakarta Administrative City, DKI Jakarta Province. The data used are primary data with the Maximum Likelihood (ML) Estimation method, recommending a sample size of 100-200. [8][11]

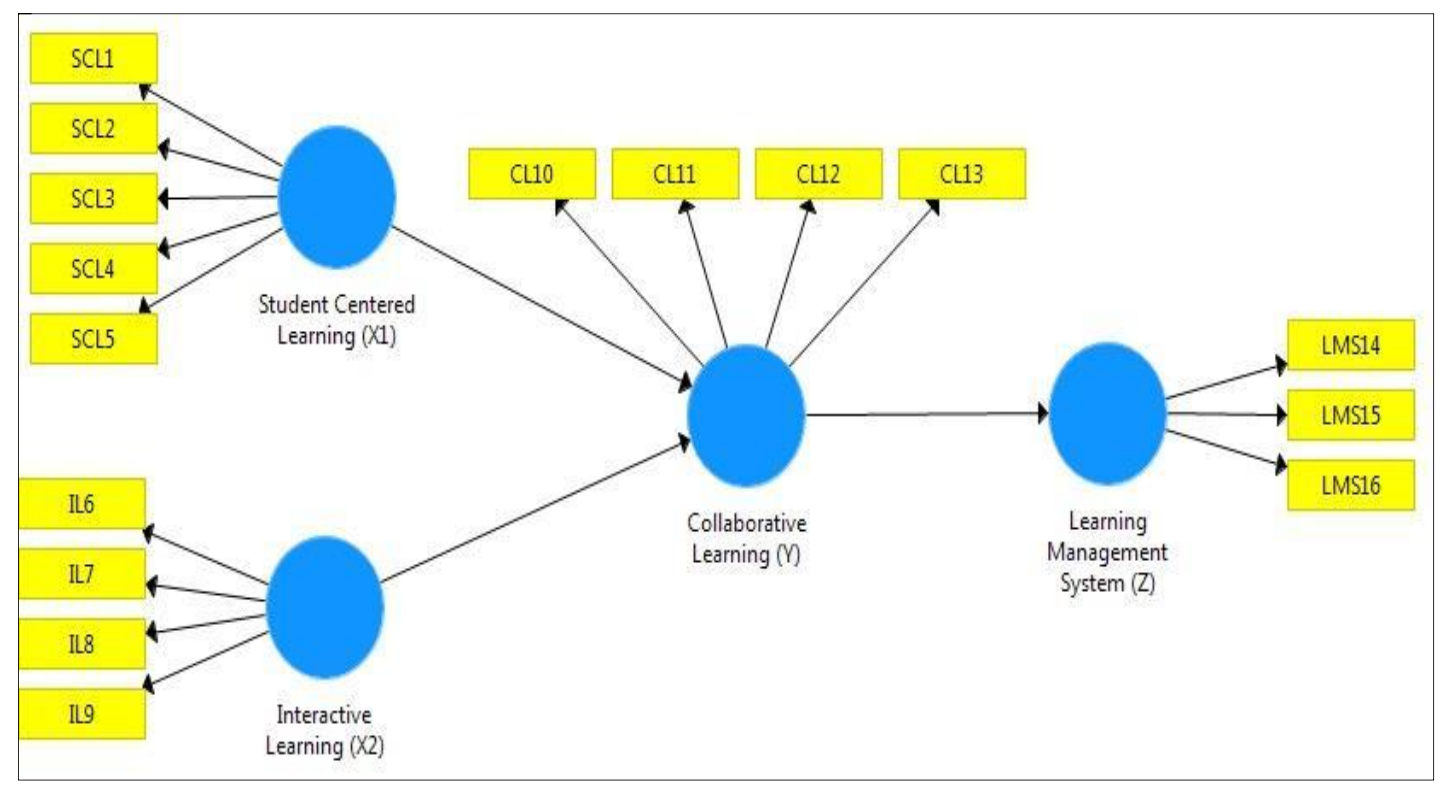

Figure 7. Design of the Research Model

The structural equation of the path diagram model:
$\mathrm{SCL}=\beta_{\mathrm{SCL}}+\mathrm{Z}_{1}$
(1)
$\mathrm{IL}=\beta_{\mathrm{IL}}+\mathrm{z}_{2}$
$\mathrm{CL}=\beta_{\mathrm{SCL}}+\beta_{\mathrm{IL}}+\mathrm{z}_{3}$
Keterangan:
$\mathrm{SCL}=$ Student Centered Learning
$\mathrm{IL} \quad=$ Interactive Learning
$\mathrm{CL} \quad=$ Collaborative Learning
LMS =Learning Management System

\section{Research Hypothesis:}

H1: The higherof implementation Student Centered Learning pillars would take effect the higher of the Collaborative Learningeffectiveness.

H2: The higher of implementation the Interactive Learning pillar would take effect of the higher the level of Collaborative Learningeffectiveness.

H3: The higher the level of $\mathrm{s}$ of Collaborative Learning effectiveness pillar would take effect the more effective the Learning Management System.

. Data collecting and identifying the level and dominant factors of the research variable indicators with Confirmatory Factor Analysis (CFA) and Structural Equation Modeling (SEM), which then become a source for creating a collaborative learning development model and LMS in the framework of learning 4.0; Software for this research using SEM PLS 3.2.4 Professional software. 
Construct analysis, theory and empirical Characteristics: (1) Collaborative Learning, Student Centered Learning, Interactiv Learning (Member 2: Ratnawati Susanto); (2.) Learning Management System (Member 1: Yulhendri); (3) Technology Readiness (Chair)

Preparation of Research Questionnaires and Interview Guidelines for identification and mapping levels and profile identification 1) Collaborative Learning, Student Centered Learning, Interactive Learning (Member 2: Ratnawati Susanto); (2.) Learning Management System (Member 1: Yulhendri); (3) Technology Readiness (Chair)

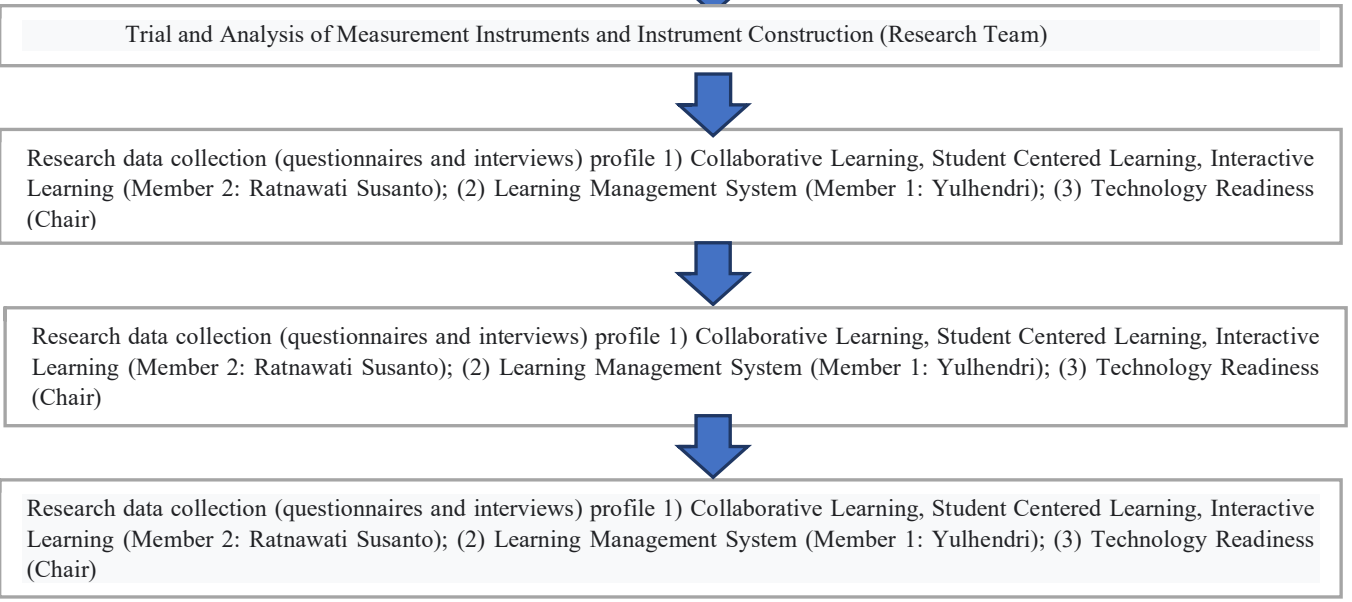

\section{RESULT AND DISCUSSION}

The respondents in this study were 310 teacher respondents from 16 research school partners in the District Education Office II, West Jakarta Administrative City, DKI Jakarta Province

The data from the research questionnaire is in the form of descriptive statistics regarding Student Centered Learning (X1) and Interactive Learning (X2) as exogenous variables. Meanwhile, Collaborative Learning (Y) and Learning Management System (Z) are endogenous variables. Analysis of Structural Equation Modeling (SEM) with Partial Least Squares (PLS) analysis technique version 3.2.4 based on descriptive statistics, namely.

Table 1 Descriptive Statistic

\begin{tabular}{|l|l|c|r|r|r|r|r|r|r|}
\hline No & Indikator & Missing & Mean & Median & Min & Max & $\begin{array}{c}\text { Standard } \\
\text { Deviation }\end{array}$ & $\begin{array}{c}\text { Excess } \\
\text { Kurtosis }\end{array}$ & Skewness \\
\hline 1 & SCL1 & 0 & 3,829 & 4,000 & 1,000 & 5,000 & 1,310 & $-1,164$ & $-0,624$ \\
\hline 2 & SCL2 & 0 & 3,774 & 4,000 & 1,000 & 5,000 & 1,300 & $-1,319$ & $-0,494$ \\
\hline 3 & SCL3 & 0 & 3,742 & 4,000 & 1,000 & 5,000 & 1,358 & $-1,249$ & $-0,550$ \\
\hline 4 & SCL4 & 0 & 3,881 & 4,000 & 1,000 & 5,000 & 1,278 & $-1,180$ & $-0,641$ \\
\hline 5 & SCL5 & 0 & 3,852 & 4,000 & 1,000 & 5,000 & 1,307 & $-1,293$ & $-0,595$ \\
\hline 6 & IL6 & 0 & 3,729 & 4,000 & 1,000 & 5,000 & 1,314 & $-1,395$ & $-0,441$ \\
\hline 7 & IL7 & 0 & 3,797 & 4,000 & 1,000 & 5,000 & 1,257 & $-1,018$ & $-0,599$ \\
\hline 8 & IL8 & 0 & 4,045 & 5,000 & 1,000 & 5,000 & 1,228 & $-0,415$ & $-0,990$ \\
\hline 9 & IL9 & 0 & 3,848 & 4,000 & 1,000 & 5,000 & 1,307 & $-1,176$ & $-0,631$ \\
\hline 10 & CL10 & 0 & 3,771 & 4,000 & 1,000 & 5,000 & 1,323 & $-1,292$ & $-0,529$ \\
\hline 11 & CL11 & 0 & 3,771 & 4,000 & 1,000 & 5,000 & 1,328 & $-1,220$ & $-0,570$ \\
\hline 12 & CL12 & 0 & 4,074 & 5,000 & 1,000 & 5,000 & 1,215 & $-0,023$ & $-1,120$ \\
\hline 13 & CL13 & 0 & 3,890 & 4,000 & 1,000 & 5,000 & 1,290 & $-1,043$ & $-0,708$ \\
\hline 14 & LMS14 & 0 & 3,861 & 4,000 & 1,000 & 5,000 & 1,294 & $-1,152$ & $-0,647$ \\
\hline 15 & LMS15 & 0 & 3,832 & 4,000 & 1,000 & 5,000 & 1,282 & $-1,193$ & $-0,579$ \\
\hline 16 & LMS16 & 0 & 3,755 & 4,000 & 1,000 & 5,000 & 1,350 & $-1,244$ & $-0,558$ \\
\hline
\end{tabular}

\section{Validity Test}

The validity test consists of convergent validity (loading factor and Average Variance Extracted (AVE)) and discriminant validity (FornellLarcker criterion and cross loadings). 


\section{Convergent Validity}

\section{Loadings Factor (Outer Loadings)}

The loadings factor value shows the correlation between the indicator and its construct. Indicators with a low loadings factor value indicate that the indicator does not work on the measurement model.

Table 2. Standardized Loadings Factor Model

\begin{tabular}{|c|c|c|c|c|}
\hline $\begin{array}{l}\text { VariabelLaten } \\
\text { Indikator }\end{array}$ & $\begin{array}{c}\text { Student } \\
\text { Centered } \\
\text { Learning } \\
\left(\mathrm{X}_{1}\right)\end{array}$ & $\begin{array}{l}\text { Interactive } \\
\text { Learning } \\
\quad\left(\mathbf{X}_{2}\right)\end{array}$ & $\begin{array}{l}\text { Collaborative } \\
\text { Learning } \\
\text { (Y) }\end{array}$ & $\begin{array}{c}\text { Learning } \\
\text { Management } \\
\text { System } \\
\text { (Z) }\end{array}$ \\
\hline SCL1 & 0,882 & & & \\
\hline SCL2 & 0,872 & & & \\
\hline SCL3 & 0,846 & & & \\
\hline SCL4 & 0,824 & & & \\
\hline SCL5 & 0,808 & & & \\
\hline IL6 & & 0,863 & & \\
\hline IL7 & & 0,826 & & \\
\hline IL8 & & 0,755 & & \\
\hline IL9 & & 0,861 & & \\
\hline CL10 & & & 0,881 & \\
\hline CL11 & & & 0,843 & \\
\hline CL12 & & & 0,725 & \\
\hline CL13 & & & 0,867 & \\
\hline LMS14 & & & & 0,883 \\
\hline LMS15 & & & & 0,877 \\
\hline LMS16 & & & & 0,827 \\
\hline
\end{tabular}

This study uses a standard loadings factor of 0.7 . The results showed that all loadings factor values for each indicator were> 0.7. In most of the references a factor weight of 0.70 or more is considered to have sufficiently strong validation to explain latent constructs. Indicators with high loadings factors have a higher contribution to explain the latent construct. In contrast, indicators with low loadings factors have a weak contribution to explain the latent construct (valid).

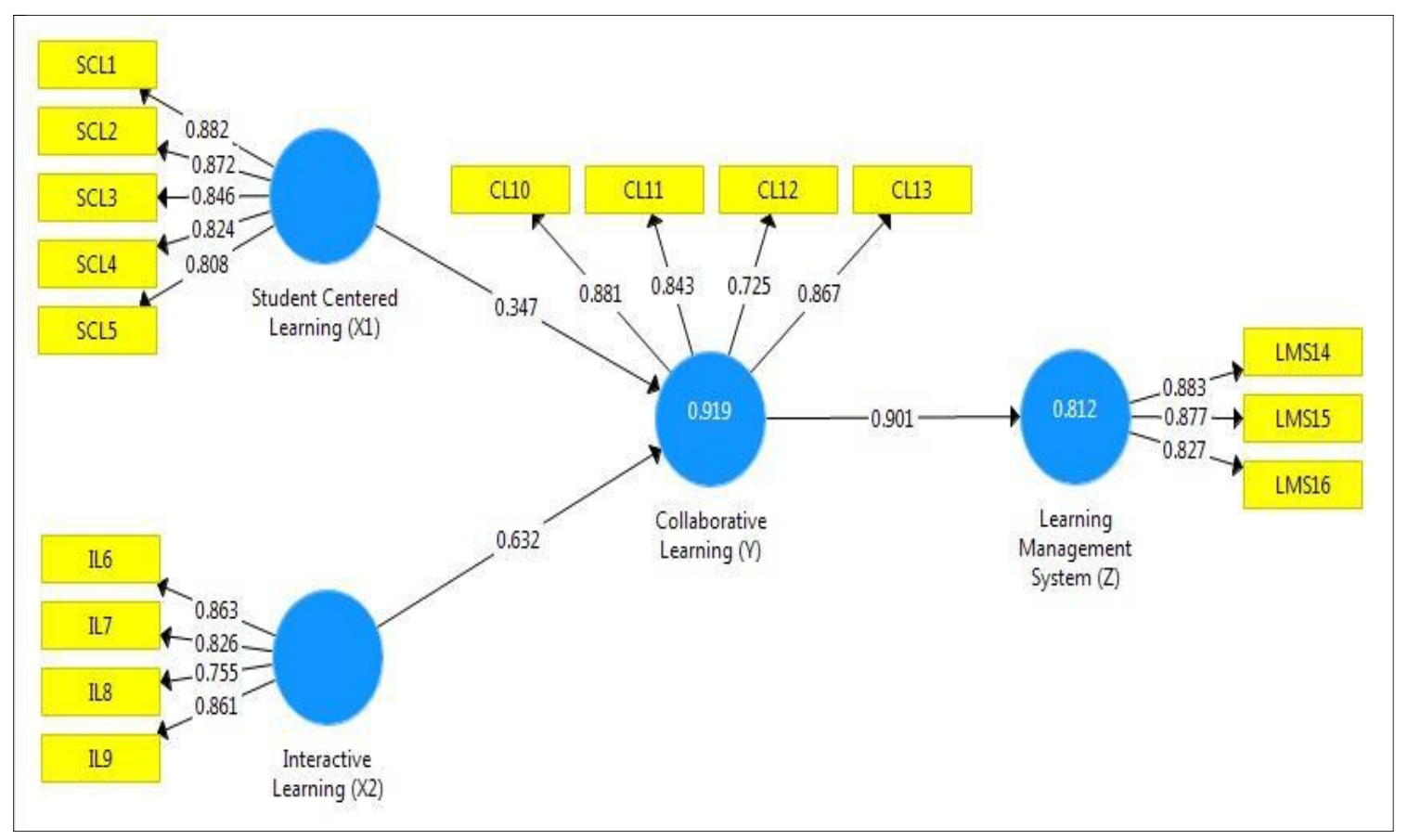

Figure 2. Measurementof OuterModel

\section{Reliability Test}

The reliability test consists of composite reliability and Cronbach's alpha. Composite reliability is the part used to test the reliability value of indicators on a variable. A variable can be declared to meet composite reliability if it has a composite reliability value $>0.7$. 
Table 3. Composite Reliability

\begin{tabular}{|l|c|}
\hline \multicolumn{1}{|c|}{ VariabelLaten } & Composite Reliability \\
\hline Student Centered Learning $\left(\mathrm{X}_{1}\right)$ & 0,927 \\
\hline Interactive Learning $\left(\mathrm{X}_{2}\right)$ & 0,896 \\
\hline Collaborative Learning $(\mathrm{Y})$ & 0,899 \\
\hline Learning Management System $(\mathrm{Z})$ & 0,897 \\
\hline
\end{tabular}

Based on Table 3 above, it shows that the composite reliability value of all research variables is $>0.7$. These results indicate that each variable has met composite reliability so it can be concluded that all variables have a high level of reliability.

Table 4. Cronbach's Alpha

\begin{tabular}{|l|c|}
\hline \multicolumn{1}{|c|}{ VariabelLaten } & Cronbach's Alpha \\
\hline Student Centered Learning $\left(\mathrm{X}_{1}\right)$ & 0,901 \\
\hline Interactive Learning $\left(\mathrm{X}_{2}\right)$ & 0,846 \\
\hline Collaborative Learning $(\mathrm{Y})$ & 0,849 \\
\hline Learning Management System $(\mathrm{Z})$ & 0,827 \\
\hline
\end{tabular}

Based on Table 4 above, it shows that the Cronbach's alpha value of each research variable is $>0.7$. The research variables have met the requirements for Cronbach's alpha value, so it can be concluded that all variables have a high level of reliability.

\section{Evaluation of Structural Model (Inner Model Test)}

The inner model test is an evaluation for the structural model consisting of the path coefficient, Rsquare, T-statistic (bootstropping), predictive relevance, and model fit.

\section{Path Coefficient}

Path coefficient evaluation is used to show how strong is the effect or influence of the independent variable on the dependent variable

Table 5. Path Coefficient

\begin{tabular}{|l|c|c|}
\hline \multicolumn{2}{|c|}{ VariabelLaten } & Path Coefficient \\
\hline $\begin{array}{l}\text { Student Centered Learning } \\
\text { Learning }(\mathrm{Y})\end{array}$ & 0,347 \\
\hline $\begin{array}{l}\text { Interactive againstCollaborative } \\
\text { Learning }(\mathrm{Y})\end{array}$ & Learning $\quad\left(\mathrm{X}_{2}\right)$ againstCollaborative & 0,632 \\
\hline $\begin{array}{l}\text { Collaborative Learning } \quad \text { (Y)againstLearning } \\
\text { Management System }(\mathrm{Z})\end{array}$ & 0,901 \\
\hline
\end{tabular}

Table 5 shows that the largest path coefficient value is shown in the effect of Collaborative Learning (Y) on Learning Management System (Z) of 0.901. The second biggest influence is Interactive Learning (X2) on Collaborative Learning (Y) of 0.632. The third biggest influence is Student Centered Learning (X1) on Collaborative Learning (Y) of 0.347 .

Based on the description of these results, it shows that all variables in this model have a positive path coefficient. This shows that, if the greater the path coefficient value on one independent variable on the dependent variable, the stronger the influence between the independent variables on the dependent variable will be.

\section{R Square Test}

Coefficient determination (R-Square) is used to measure how much endogenous variables are affected by other variables. R2 results of 0.67 and above indicate that the endogenous latent variables in the structural model indicate the effect of exogenous variables (which influence) on endogenous variables (which are influenced) is in the good category. Meanwhile, if the result is $0.33-0.67$, it is in the medium category, and if the result is $0.19-0.33$ it is in the weak category [9]. Based on data processing that has been done using SEM PLS 3.2.4 Professional software, the R Square value is obtained as follows: 
Table6. $R$ Square

\begin{tabular}{|l|c|}
\hline \multicolumn{1}{|c|}{ VariabelLaten } & R Square \\
\hline Collaborative Learning $(\mathrm{Y})$ & 0,919 \\
\hline Learning Management System $(\mathrm{Z})$ & 0,812 \\
\hline
\end{tabular}

Table 6 shows The R-Square value for the Collaborative Learning (Y) variable is 0.919 . The acquisition of this value explains that the percentage of Collaborative Learning can be explained by Student Centered Learning and Interactive Learning of $91.9 \%$. The remaining $8.1 \%$ is influenced by variables outside Student Centered Learning and Interactive Learning such as teacher centered learning, learning motivation, school environment and so on.

The R Square value of the Learning Management System $(\mathrm{Z})$ variable is 0.812 . The acquisition of this value explains that the percentage of the Learning Management System can be explained by Collaborative Learning at $81.2 \%$. The remaining $18.8 \%$ is influenced by variables outside of collaborative learning such as teacher centered learning, learning motivation, the school environment and so on.

\section{Hypothesis Testing (T-Statistics)}

Hypothesis testing is done by looking at the T-Statistics value and the P-Values value. The research hypothesis can be stated as accepted if the P-Values value $<0.05$ [10].

Table 7. T-Statistics dan P-Values

\begin{tabular}{|l|l|c|c|c|}
\hline Hipotesis & \multicolumn{1}{|c|}{ Pengaruh } & T-Statistics & P-Values & Keterangan \\
\hline $\mathrm{H}_{1}$ & $\begin{array}{l}\text { The higherof applicationSCL pillars } \\
\text { would affect the higher of the CL } \\
\text { effectiveness. }\end{array}$ & 5,263 & 0,000 & Be accepted \\
\hline $\mathrm{H}_{2}$ & $\begin{array}{l}\text { The higher of implementation the IL } \\
\text { pillar would affect of the higher the } \\
\text { level of CLeffectiveness. }\end{array}$ & 9,898 & 0,000 & Be accepted \\
\hline $\mathrm{H}_{3}$ & $\begin{array}{l}\text { The higher the level of CL } \\
\text { effectiveness pillar would affect the } \\
\text { more effective the LMS }\end{array}$ & 65,434 & 0,000 & Be accepted \\
\hline
\end{tabular}

Based on Table 7 above, it shows that the effect of Student Centered Learning on Collaborative Learning with a T-Statistic value of 5.263> a T-table value of $1.967(\alpha=0.05)$ and a P-Value of $0.000<\alpha=$ 0.05. Thus, there is a positive and significant effect of Student Centered Learning on Collaborative Learning. This means that the higher the pillars of implementing Student Centered Learning, the higher the level of effectiveness of Collaborative Learning.

The effect of Interactive Learning on Collaborative Learning with a T-Statistic value of 9.898> a T-table value of $1.967(\alpha=0.05)$ and a P-value of $0.000<\alpha=0.05$. Thus, there is a positive and significant effect of Interactive Learning on Collaborative Learning. This means that the higher the pillars of implementing Interactive Learning, the higher the level of effectiveness of Collaborative Learning.

The effect of Collaborative Learning on Learning Management System with a T-Statistic value of $65,434>$ a T-table value of $1,967(\alpha=0.05)$ and a P-value of $0,000<\alpha=0.05$. Thus, there is a positive and significant effect of Collaborative Learning on the Learning Management System. This means that the higher the pillars of implementing Collaborative Learning, the higher the level of effectiveness of the Learning Management System.

Thus, the three hypotheses proposed in this study are accepted. This is because each of the effects shown has a T-Statistic value $>$ a T-table value of $1.967(\alpha=0.05)$ and a P-Values value $<0.05$. So that it can be stated that exogenous variables on endogenous variables have a positive and significant effect.

\section{Predictive Relevance Test}

The PLS model was evaluated by looking at the predictive relevance (Q-square) for the constructive model. Q-square aims to measure how well the observed value is generated by the model and also its parameter estimates. The measurement criteria are sure, if the Q-square is greater than 0 (zero), it shows that 
the model has a predictive relevance value. If the Q-square value is less than 0 (zero), it shows that the model lacks predictive relevance. However, if the calculation results show that the Q-square value is more than 0 (zero), then the model deserves to be said to have a relevant predictive value. The results of the predictive relevance (Q-square) calculation are as follows:

Table8. Predictive Relevance

\begin{tabular}{|l|c|}
\hline \multicolumn{1}{|c|}{ VariabelLaten } & Q-Square \\
\hline Collaborative Learning (Y) & 0,597 \\
\hline Learning Management System (Z) & 0,573 \\
\hline
\end{tabular}

Table 8 shows that the Q-square value of Collaborative Learning $(\mathrm{Y})$ is 0.597 ; and the Q-square Learning Management System $(Z)$ value of 0.573 . The results of the calculation show that the Q-square value is more than 0 (zero), so the model can be said to have a good observed value.

\section{Fit Model}

The model goodness test (Model Fit) with the Normed Fit Index (NFI) is a measure of the suitability of the model on a comparative basis to the base line or the null model. The null model is generally a model which states that the variables contained in the estimated model are not interrelated.

Table9.Model Fit

\begin{tabular}{|l|c|}
\hline \multicolumn{1}{|c|}{ Model Fit } & Nomed Fix Index (NFI) \\
\hline Saturated Model & 0,593 \\
\hline Estimated Model & 0,580 \\
\hline
\end{tabular}

Based on the results of the above calculations, the Nomed Fix Index (NFI) value is 0.593 . Thus the research model studied was $59.3 \%$ in the fit or good category.

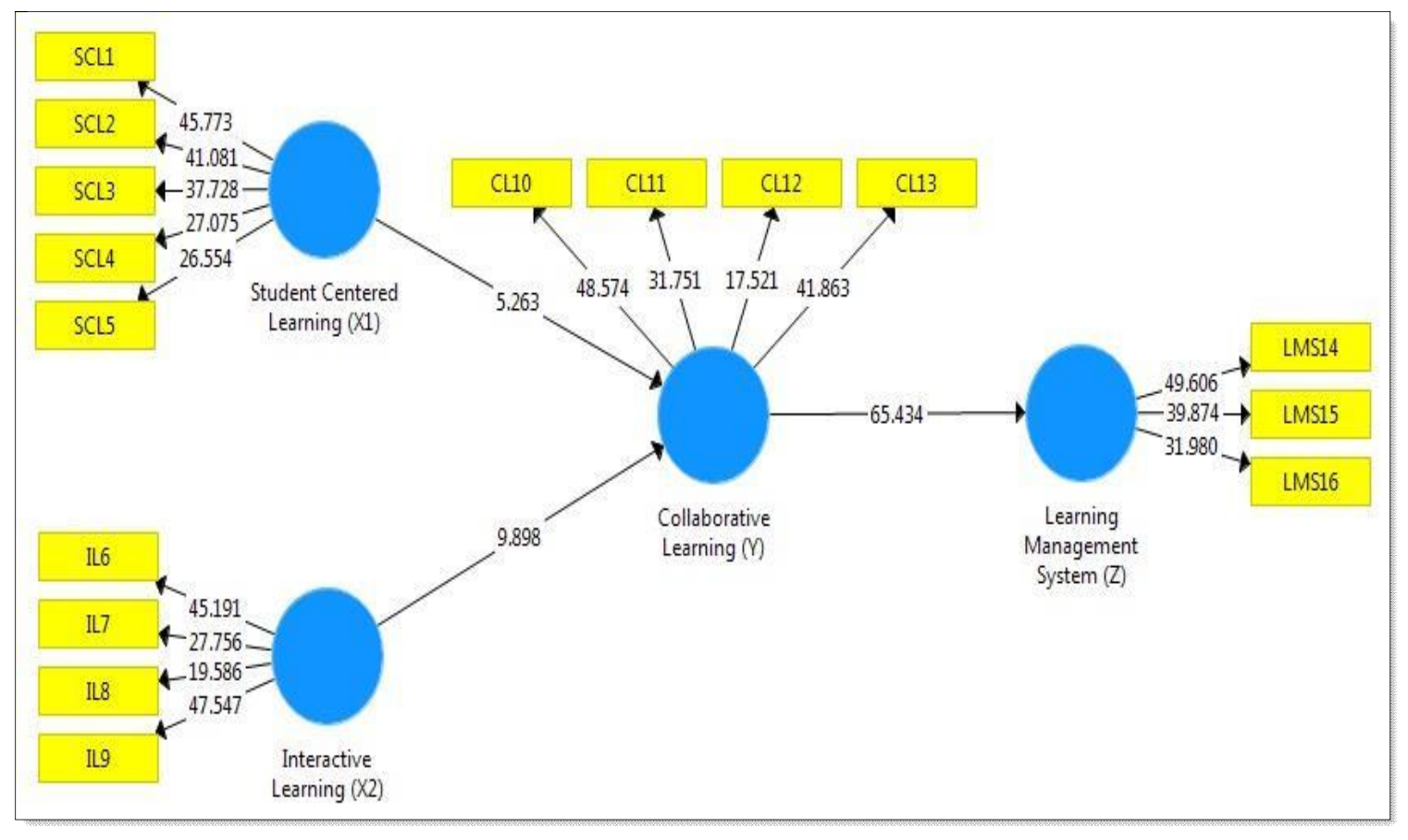

\section{CONCLUSION}

Figure 3. Inner Model Measurement

Based on the results of hypothesis testing, several research findings were obtained, namely:

1. Student Centered Learning has a positive and significant effect on Collaborative Learning. This means that the higher the pillars of implementing Student Centered Learning, the higher the level of effectiveness of Collaborative Learning. 
2. Interactive Learning has a positive and significant effect on Collaborative Learning. This means that the higher the pillars of implementing Interactive Learning, the higher the level of effectiveness of Collaborative Learning.

3. Collaborative Learning has a positive and significant effect on the Learning Management System. This means that the higher the pillars of implementing Collaborative Learning, the higher the level of effectiveness of the Learning Management System.

\section{ACKNOWLEDGEMENT}

The author are grateful to the EsaUnggul Rector and Dean for supporting motivation and funds to finished this research, all of our Primary School headmaster and teacher in the West Jakarta City as a research respondent. We also thank to Denni Kurniawan for invaluable advices.

\section{REFERENCE}

[1] I. Ahmad, "Proses Pembelajaran Digital dalam Era Revolusi Industri 4 . 0 Era Disrupsi Teknologi," in Kementerian Riset, Teknologi, dan Pendidikan Tinggi, Medan: Dirjen Kementerian, Riset, Teknologi dan pendidikan Tinggi, 2018, pp. 1-13.

[2] A. Supriatna, "Kegiatan Lesson Study sebagai Upaya Guru untuk Menemukan Pembelajaran yang Memenuhi Keperluan Anak Hidup pada Zamannya (Era Revolusi Industri 4.0)," Edusainstek, vol. 1, no. 1, pp. 1-5, 2018.

[3] H. Suwardana, "117-265-1-Sm,” JATI UNIK J. Ilm. Tek. dan Manaj. Ind., vol. 1, no. 2, pp. 102-110, 2018.

[4] K. Harto, "Tantangan Dosen Ptki Di Era Industri 4.0," J. Tatsqif, vol. 16, no. 1, pp. 1-15, 2018.

[5] I. SEPTIANA, A. SEPTIANA, P. SEPTIANA, S. SEPTIANA, and A. SAREGAR, "Temperature and Heat Learning Through SSCS Model with Scaffolding: Impact on Students Critical Thinking Ability," J. Educ. Gift. Young Sci., vol. 6, no. 3, pp. 39-54, 2018.

[6] S. I. A. Dwiningrum, "Culture-Based Education to Face Disruption Era," 3rd Natl. Semin. Educ. Innov. (SNIP 2018), vol. 1, no. 2, pp. 20-38, 2018.

[7] Aguswuryanto, Permenpan No 16 Tahun 2009 Tentang Jabatan Fungsional Guru dan Angka Kreditnya. 2010.

[8] I. Ghozali, Model Persamaan Struktural, Konsep dan Aplikasi dengan Amos 24. Semarang: Badan Penerbit Universitas Diponegoro, 2017, p.25.

[9] I.Ghozali, Structural Equation Modeling - MetodeAlternatifdengan Partial Least Squares (PLS). Semarang: UniversitasDiponegoro, 2014, p. 39.

[10] S. Yamin dan H. Kurniawan, Generasi Baru Mengolah Data Penelitian dengan Partial Least Square Path Modeling. Jakarta: Salemba Empat, 2011, p. 54.

[11] Tjahjono, B, Mukhtar, M, Abdullah, T, The Effect of Transformational Leadership, Organization Culture, Innovation to Lecturer's Performance, Proceeding of ICELS, 2019, Scitepress, pp. 82-90, DOI:10.5220/0008994200820090 